九州大学学術情報リポジトリ

Kyushu University Institutional Repository

\title{
Interspecific Hybridization with Camellia chrysantha
}

Hwang, Yueh-Jiang

Laboratory of Horticultural Science, Faculty of Agriculture, Kyushu University

Okubo, Hiroshi

Laboratory of Horticultural Science, Faculty of Agriculture, Kyushu University

Fujieda, Kunimitsu

Laboratory of Horticultural Science, Faculty of Agriculture, Kyushu University

Uemoto, Shunpei

Laboratory of Horticultural Science, Faculty of Agriculture, Kyushu University

https://doi.org/10.5109/23910

出版情報 : 九州大学大学院農学研究院紀要. 34 (4)，pp.427-433，1990-03. Kyushu University バージョン：

権利関係 : 


\title{
Interspecific Hybridization with Camellia chrysantha
}

\author{
Yueh-Jiang Hwang, Hiroshi Okubo, Kunimitsu Fujieda and \\ Shunpei Uemoto*
}

Laboratory of Horticultural Science, Faculty of Agriculture, Kyushu University 46-01, Fukuoka 812, Japan

(Received November 22, 1989)

\begin{abstract}
To breed new yellow flowered camellias, Camellia chrysantha var. chrysantha and var. microcarpa were adopted to cross with 9 other Camellia species. Thirteen embryos obtained from 247 pollinations were cultured on Anderson's medium. Six of them developed to plantlets, but only 3 survived after habituation. Two plants were from C. crapnelliana and 1 from C. granthamiana, both crossed with C. chrysantha var. microcarpa. Morphological and isozyme studies confirmed them truly interspecific.
\end{abstract}

\section{INTRODUCTION}

The yellow flowered camellia, Camellia chrysanthu, was introduced to Japan and the western nations from the People's Republic of China in 1979 (Hagiya, 1982). Although the yellow but small flowers are usually nodding and hidden under the large leaves, it is still considered to be the most promising parent to breed new camellias of large yellow or orange flowers. Due to its cross-incompatibility with other camellias (Hagiya, 1982), only combination of C. japonica $\times$ C. chrysanthu (Yamaguchi et al., 1987 ; Uemoto et al., 1988), C. reticulata X C. chrysanthu and C. pitardii var. yunnanensis $\times$ C. chrysanthu (Xia, 1984) and C. vietnamensis $\times$ C. chrysanthu (Nadamitsu et al., 1986) have been successful. Since flowers of desirable colors and shapes have not yet been obtained, other interspecific hybrids of $\mathrm{C}$. chrysantha are required.

Embryo culture has been a great aid in obtaining $F_{1}$ hybrids in a wide range of genera such as Camellia (Yamaguchi et al., 1987), Lilium (Asano and Myodo, 1977, 1978), Helianthus (Chandler and Beard, 1983),Cucurbita (Wall, 1954), etc., in all of which the interspecific $F_{1}$ plants are hardly obtainable by conventional methods of crossing. Liang et al. (1986) reported that hybrid embryos of C. pitardii var. yunnanensis x C. chrysanthu aborted during plumule differentiation. To avoid abortion of hybrid embryo and to shorten germination time, we adopted embryo culture.

Comparisons of morphological characteristics and isozyme banding patterns of leaf tissue of the hybrids were executed to confirm them interspecific.

\section{MATERIALS AND METHODS}

Camellia species used in this experiment are listed in Table 1. They were grown in a greenhouse except for 3 cultivars of C. japonica which were planted in the open field. The flowers of pistilate parents were emasculated and covered with paper bags

\footnotetext{
* Present address; Faculty of Agriculture, Iwate University, Morioka 020
} 
Table 1. Listing of subgeneric sections, species and varieties, and their $2 \mathrm{n}$ chromosome number of camellias used for hydridization.

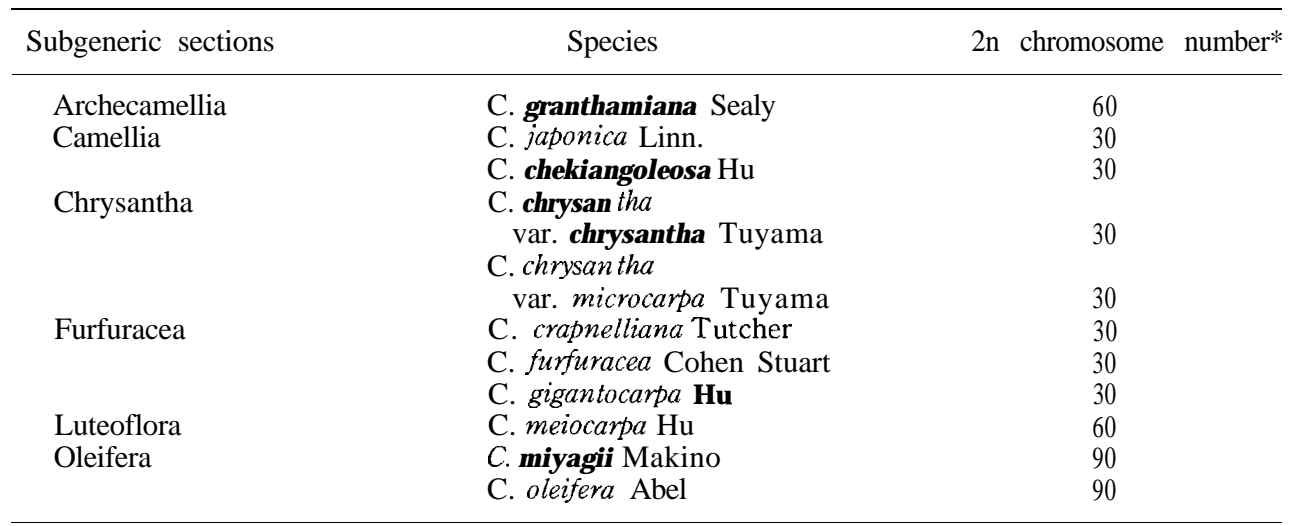

${ }^{*}$ Hakoda, N. and N. Adachi, 1985

one day before anthesis, and then pollinated on the next day with fresh pollen from $\mathrm{C}$. chrysantha var. chrysanthu or C. chrysanthu var. microcarpa from November 15, 1986 to February 10, 1987. All pollinated pistils were covered again with paper bags for isolation.

Seeds were taken out from capsules after harvest from June 27 to August 3, 1987, and number of capsules set and fruiting percentage (number of capsules set/number of flowers pollinated) were recorded. Embryo development and the number were examined on a clean-bench. Immature embryos of various size, ranging from 1 to 8 $\mathrm{mm}$ in diameter, were excised and placed on Anderson's medium (Anderson, 1984), supplemented with $30 \mathrm{~g} / \mathrm{Z}$ sucrose and $2 \mathrm{~g} / \mathrm{Z}$ gellan gum but not with any plant hormone. The medium was adjusted to $\mathrm{pH} 5.5$ and distributed $10 \mathrm{ml}$ to each tube before autoclaving $\left(121^{\circ} \mathrm{C}, 15 \mathrm{~min}\right)$. The cultures were incubated at $25^{\circ} \mathrm{C}$ under continuous light supplied by cool white fluorescent lamps, giving an intensity about 800 lux, for approximately six months. They were then subcultured on $20 \mathrm{ml}$ fresh medium of the same constitution for additional three months. Plantlets obtained in test tubes were taken out and rinsed with tap water to remove gellan gum. They were transplanted in sterile vermiculite in $9 \mathrm{~cm}$ pots in diameter and grown in a shaded greenhouse.

Phosphoglucose isomerase (PGI) of the mature, fully expanded leaves of habituated $F_{1}$ progenies and of their parents were resolved by starch gel electrophoresis. Extraction and staining procedures, and gel and buffer compositions followed the methods of Wendel and Parks (1982).

\section{RESULTS AND DISCUSSION}

Among 3 cultivars of $\mathrm{C}$. japonica pollinated by C. chrysanthu var. chrysantha, only 'Hatsuarashi' showed $12 \%$ fruit set, while the others bore nothing (Table 2). There seems to be some cultivar difference in cross compatibility within the species, and more cultivars should be tried for obtaining hybrids with this species. Camellia 
Table 2. Fruits, seeds and embryos obtained from 7 Camellia species pollinated by C. chrysantha var. chrysantha.

\begin{tabular}{|c|c|c|c|c|}
\hline \multirow{2}{*}{$\begin{array}{l}\text { Species and } \\
\text { cultivars }\end{array}$} & \multirow{2}{*}{$\begin{array}{l}\text { No. of } \\
\text { pollinated } \\
\text { flowers }\end{array}$} & Capsule set & \multirow{2}{*}{$\begin{array}{c}\text { No. of } \\
\text { seeds } \\
\text { obtained }\end{array}$} & \multirow{2}{*}{$\begin{array}{l}\text { No. of } \\
\text { embryos } \\
\text { obtained }\end{array}$} \\
\hline & & No. $\left(\%^{*}\right)$ & & \\
\hline \multicolumn{5}{|l|}{ C. japonica } \\
\hline 'Muruishibori' & 27 & $0 \quad(0 \%)$ & 0 & 0 \\
\hline 'Shiragiku' & 32 & $0 \quad(0 \%)$ & 0 & 0 \\
\hline 'Hatsuarashi' & 34 & $4 \quad(12 \%)$ & 6 & 0 \\
\hline C. chekiangoleosa & 11 & $7 \quad(64 \%)$ & 42 & \\
\hline C. crapnelliana & 3 & $0 \quad(0 \%)$ & 0 & 0 \\
\hline C. furfuracea & 3 & $1 \quad(33 \%)$ & & 0 \\
\hline C. gigan tocarpa & & $(29 \%)$ & 5 & 0 \\
\hline C. meiocarpa & 9 & $2 \quad(22 \%)$ & 3 & 0 \\
\hline C. oleifera & 2 & $1 \quad(50 \%)$ & 1 & 1 \\
\hline
\end{tabular}

*No. of capsules set / No. of pollinated flowers

Table 3. Fruits, seeds and embryos obtained from 6 Camellia species pollinated by C. chrysantha var. microcarpa.

\begin{tabular}{|c|c|c|c|c|c|}
\hline Species & $\begin{array}{c}\text { No. of } \\
\text { pollinated } \\
\text { flowers }\end{array}$ & & 0. $\left(\%^{*}\right)$ & $\begin{array}{c}\text { No. of } \\
\text { seeds } \\
\text { obtained }\end{array}$ & $\begin{array}{c}\text { No. of } \\
\text { embryos } \\
\text { obtained }\end{array}$ \\
\hline C. crapnelliana & 7 & 2 & $(29 \%)$ & 7 & 2 \\
\hline C. furfuracea & 22 & 11 & $(50 \%)$ & 22 & 0 \\
\hline C. gigan tocarpa & 24 & 8 & $(33 \%)$ & 27 & 0 \\
\hline C. granthamiana & 10 & 2 & $(20 \%)$ & 3 & 3 \\
\hline C. miyagii & 33 & 18 & $(55 \%)$ & 14 & 6 \\
\hline C. oleifera & 23 & 1 & $(4 \%)$ & 1 & 0 \\
\hline
\end{tabular}

'No. of capsules set / No. of pollinated flowers

chekiangoleosa gave the highest percentage of fruit set and 42 seeds were obtained, whereas the other species-except C. crapnelliana, which bore nothing-set only 1 to 5 seeds. Unfortunately, most of the seeds were empty or endosperm without embryo, indicating that some of the embryos degenerated and disappeared at a very early stage. Two embryos were obtained from the total of 58 seeds, one of which was the progeny of C. chekiangoleosa and the other was the offspring of C. oleifera both of which had been crossed with $\mathrm{C}$. chrysantha var. chrysantha.

Six species of Camellia were selected to be crossed with C. chrysantha var. microcarpa. The combinations of C. furfuracea X C. chrysanthu var. microcarpa and C. miyagi $\mathrm{x}$ C. chrysanthu var. microcarpa gave the best results with more than $50 \%$ of fruit set, while moderate or poor percentage of fruit set was obtained in other crossings, among which C. oleifera $\times$ C. chrysanthu var. microcarpa showed the lowest fruit set. Eleven embryos were obtained from 74 seeds. Two of them were the offspring of C. crapnelliana x $\mathbf{C}$. chrysantha var. microcarpa, $\mathbf{3}$ obtained from the combination of C. granthamiana $\times$ C. chrysanthu var. microcarpa, and the other 6 were progenies of C. miyagii x C. chrysanthu var. microcarpa (Table 3). It seems that $\mathbf{C}$. chrysantha var. microcarpa is more compatible with other camellias than the variety of 
chrysantha. Even though this bears smaller flowers than the var. chrysantha, it may be more useful in cross breeding.

Totally, 13 embryos, some were malformed, from the crossings with either var. chrysanthu or microcarpa were cultured. Some of them died very soon during the embryo culture, but six plantlets survived (Table 4).

Hilsman (1966) and Savige (1967) reported that the most successful crosses in Camellia breeding were found within the same section, particularly the species with the same ploidy. Hagiya $(1982,1986)$ also found that the Camellia species belonging to the same section are more compatible than the species of different sections, and in cases of intersectional crosses, those with the same ploidy are more compatible than those with different chromosome numbers. Ackerman (1973) showed that species of certain sections are more closely related to each other than to species of other section based on the cross compatibility between their representative species. Compatibility of $\mathrm{C}$. chrysanthu and other Camellia species was very low in our experiments. This could be attributed to the distantly intersectional crosses. However, the compatibility of $\mathrm{C}$. chrysanthu crossing with the species in different sections with different ploidies was not always lower than that in different sections with the same ploidies in our crossing tests.

In order to bring embryos up into healthy seedlings, Liang et al. (1986) mentioned that it was necessary to isolate hybrid embryos of C. pitardii var. yunnanensis $\times \mathbf{C}$. chrysanthu before plumule differentiation to culture in vitro. In our study, the hybrid embryos obtained were not uniform in size, and we observed that the size of hybrid embryos was one of the important factors affecting their survival. All the embryos of which the size was less than $2 \mathrm{~mm}$ in diameter died during the culture. To ensure a hybrid embryo of camellia to both survive and develop as a plant, the embryo must be at least larger than $3 \mathrm{~mm}$, which is about $1 / 4$ of a normal size. Progressed culture technique should be studied to rescue these small and incompletely developed embryos.

Generally, a camellia is two-cotyledoned, but C. chrysanthu has 3 to 6 cotylendons, in which 3 to 4 are more commonly found. The hybrid embryos had 2,3 or 4 cotyledons (Fig. 1). Their initial color was cream and gradually became reddish-purple or dark greenish-purple during the culture in test tubes. The shoots were also dark purple like

Table 4. Results of embryo culture of F, hybrids.

\begin{tabular}{|c|c|c|c|c|}
\hline Parentage & & $\begin{array}{l}\text { Number of } \\
\text { embryos } \\
\text { cultured }\end{array}$ & $\begin{array}{l}\text { Number of } \\
\text { plantlets } \\
\text { obtained }\end{array}$ & $\begin{array}{l}\text { Survival* } \\
\text { rate }\end{array}$ \\
\hline $\begin{array}{l}\text { C. chekiangoleosa } \\
\text { C. oleifera }\end{array}$ & $\begin{array}{l}\text { × C. chrysanthu } \\
\text { var. chrysantha } \\
\times \text { C. chrysantha }\end{array}$ & 1 & 1 & 1.00 \\
\hline C. crapnelliana & $\begin{array}{l}\text { var. chrysanthu } \\
\text { × C. chrysantha }\end{array}$ & 1 & 0 & 0.00 \\
\hline C. gran thumiana & $\begin{array}{l}\text { var. microcarpa } \\
\times \text { C. chrysantha }\end{array}$ & 2 & 2 & 1.00 \\
\hline \multirow{2}{*}{ C. miyagii } & $\begin{array}{l}\text { var. microcarpa } \\
\times C \text {. chrysanthu }\end{array}$ & 3 & 1 & 0.33 \\
\hline & var. microcarpa & 6 & 2 & 0.33 \\
\hline
\end{tabular}

*Number of plantlets obtained / number of embryos cultured 


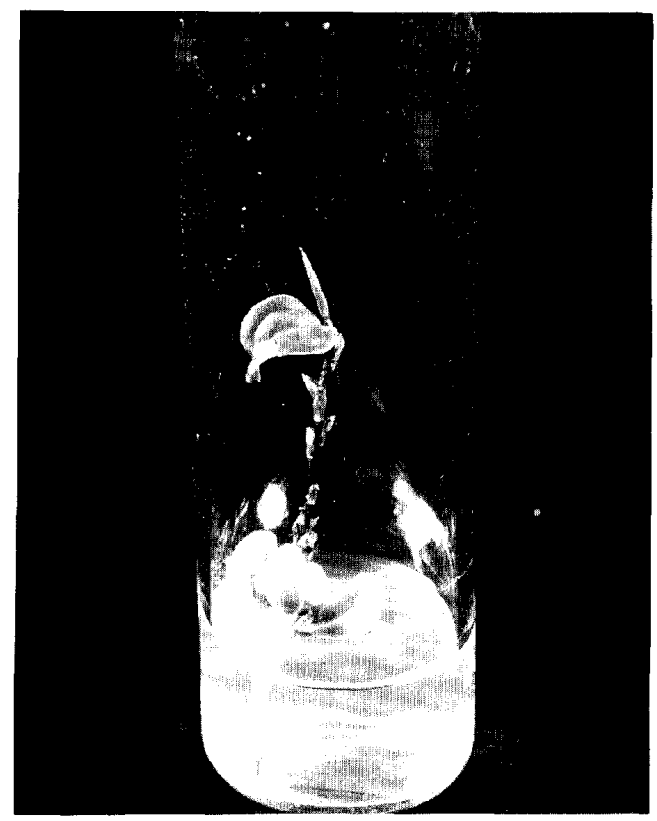

Fig. 1. A plantlet from a four cotylendon embryo of C. granthamiana $\mathbf{x}$ C . chrysanthu var. microcarpa.

the color of C. chrysantha shoot.

Because of distant hybridization, some hybrid seedlings were very weak. After being planted out, half of the plantlets obtained from embryo culture gradually died. The survivors, however, including two $\mathrm{F}_{1}$ 's of C. crapnelliana $\times$ C. chrysanthu var. microcarpa and one $F_{1}$ of $C$. granthamiana $\times$ C. chrysanthu var. microcarpa grew vigorously in the greenhouse.

Results of isozyme analysis of their leaves are given in Fig. 2. One band of PGI isozyme migrated anodally at $36 \mathrm{~mm}$ in $\mathrm{F}_{1}$ 's and their pollen parent $\mathrm{C}$. chrysanthu var. microcarpa, but not in any mother parent (Fig. 2). The isozyme banding pattern and the morphological characteristics prove that these offspring plants are truly interspecific hybrids.

Our results suggest that there are possibilities to obtain more interspecific hybrids than those already obtained with C. chrysanthu by crossing and embryo culture. In this experiment, the hybridization was carried out in only one direction, the reversed direction and other combinations with C. chrysanthu should be tried.

\section{REFERENCES}

Ackerman, W. L. 1973 Species compatibility relationships within the genus Camellia. J.Hered., 64 : 356-358

Anderson, W. C. 1984 A revised tissue culture medium for shoot multiplication of Rhododendron.

J. Amer. Soc. Hort.Sci., 109: 343-347

Asano, Y. and H. Myodo 1977 Studies on crosses between distantly related species of lilies II. The 


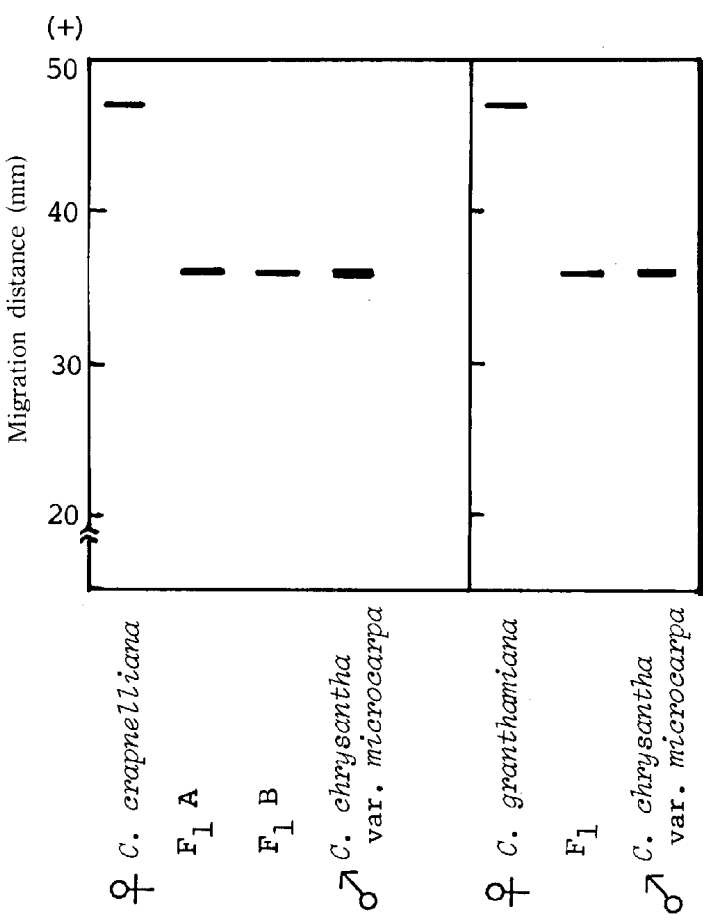

Fig. 2. Schematic presentation of the zymogram of phosphoglucose isomerase in $3 F_{1}$ progenies and their parents.

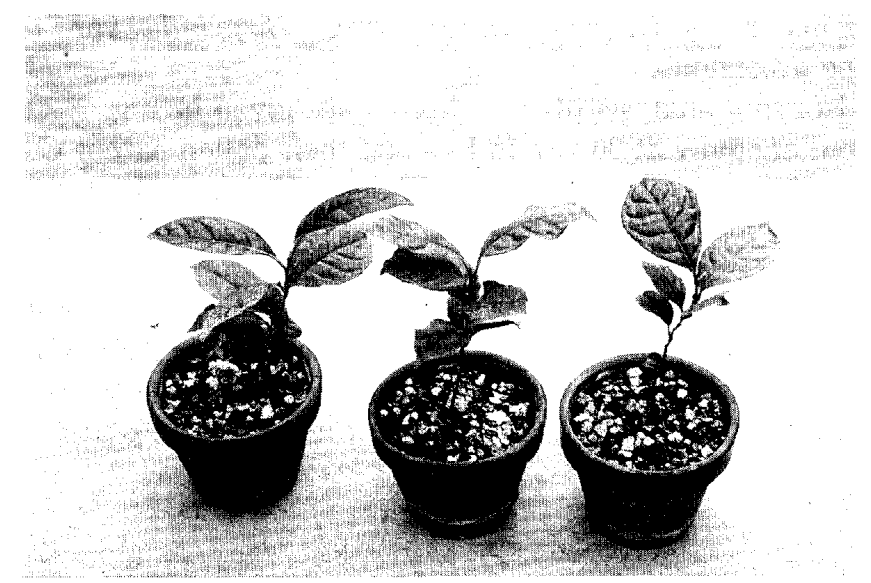

Fig. 3. Plants derived from embryos of C. crapnelliana $\times$ C. chrysantha var. microcarpa (left 2) and C. granthamiana $\times$ C. chrysantha var. microcarpa (right). 
culture of immature hybrid embryos. J. Japan. Soc.Hort. Sci., 46: 267-273

Asano, Y. and H. Myodo 1978 Studies on crosses between distantly related lilies III. New hybrids obtained through embryo culture, J.Japan. Soc. Hort.Soc., $47: 401-414$

Chandler, J. M. and B. H. Beard 1983 Embryo culture of Helianthus hybrids. Crop Sci., 23 :1004 1007

Hagiya, K. 1982 Interspecific hybridization of Camellias using C. chrysantha pollen (Preliminary report). Tsubaki 21: 1-6

Hagiya, K. 1986 Studies on interspecific hybridization of Camellia. Bull. Seibu Maizuru Botanical Institute $2:$ :-24

Hakoda, N. and N. Adachi 1985 The species of the genus Camellia- the collections of SeibuMaizuru Botanical Institute. Bull. Seibu Maizuru Botanical Institute, 1 : 1-54

Hilsman, P. L. 1966 Interspecific Camellia hybrids. Amer. Camellia Soc.Yrbk., pp. 113-114

Liang, H., Z. Zhang and X. Zhang 1966 Investigation of the sexual process in interspecific crosses between Camellia pitardii var. yunnanensis and C. chrysantha. Acta Bot. Yunnanica 8 : 147-152

Nadamitsu, S., Y. Andoh, K. Kondo and M. Segawa 1986 Interspecific hybrids between Camellia vietnamensis and C. chrysantha by cotylendon culture. Japan. J . Breed., 36: 309-313

Savige, T. 1967 Camellia species and hybrids. Amer. Camellia Soc. Yrbk., pp. 77-100

Uemoto, S., I. Miyajima and T. Eguchi 1988 Floral pigmentation in $F_{1}$ hybrid plant between Camellia japonica and C. chrysantha. Int. Camellia $J$., $20:$ 44-46

Wall, J. R. 1954 Interspecific hybrids of Cucurbita obtained by embryo culture. Proc. Amer. Soc. Hort. Sci., 63 : 427-430

Wendel, J. F. and C. R. Parks 1982 Genetic control of isozyme variation in Camellia japonica L. J. Hered., 73 : 197-204

Xia, L. 1984 Seedling breeding with Camellia chrysantha. Int. Camellia J., 16: 18-20

Yamaguchi, S., K. Tomita and S. Hisatomi 1987 Interspecific hybrid between Camellia japonica cv. Chochidori and C. chrysantha produced by embryo culture. Japan. J. Breed., 37 : 203-206 